\title{
Firewood Transport by National and State Park Campers: A Risk for Native or Exotic Tree Pest Movement
}

\author{
W.R. Jacobi, B.A. Goodrich, and C.M. Cleaver
}

\begin{abstract}
Untreated firewood has the potential to harbor insects or pathogens lethal to trees in urban and natural forest ecosystems. Campers at 15 campgrounds in seven Colorado, U.S., State Parks and 30 campgrounds in 13 National Parks in Arizona, Colorado, Nevada, Utah, and Wyoming were surveyed in 2007-09 to determine camper home states, firewood presence, firewood state origins and risks of firewood harboring pests. Sixty-six percent of Colorado State Park campers had firewood but only $4 \%$ had firewood brought from out-of-state origins. Sixty percent of National Park campers had firewood and $39 \%$ had firewood from out of state, equating to 329,919 campers potentially bringing out-of-state firewood in one year to surveyed parks. Forty-one percent of out-of-state firewood was brought by campers from nonneighboring states, indicating long distance transport of firewood occurs. Of all firewood present in National Parks, 32\% was purchased inside the park, 25\% was purchased outside the park and 17\% was from camper residences. Fifty-three percent of firewood had evidence of previous insect presence and 39\% had fungal infestation. Camper movement of untreated firewood has the potential to be a high risk pathway for distribution of live tree pests throughout North America, and educational and mitigation actions should be implemented.

Key Words. Campgrounds; Exotic Pests; Firewood; Invasive Pests; National Parks; Pathway Risk Analysis; State Parks; Unprocessed Wood; Urban Pests.
\end{abstract}

Firewood is an ideal habitat for many pests, and long-distance dispersal by humans can facilitate insect introductions or disease infestations in urban and natural forests (Liebhold et al. 1995; Allen and Humble 2002; Tkacz 2002; Crocker et al. 2007; National Plant Board 2010). While many National and State Park campgrounds sell firewood on site, campers may arrive with firewood, either purchased in small bundles at retail stores or cut and collected from home or other locations. There are several recognized pathways for the movement of tree pathogens and insect pests within the United States, including nursery stock, logs and other unprocessed wood, and wood packing materials (Liebhold et al. 1995; Poland et al. 1998; Tkacz 2002; Pimental et al. 2005; Haack 2006; Lawrence 2006); however, little research exists on the risks of moving tree pests into new environments by transporting firewood to popular recreation and camping areas in the western United States.

Exotic (nonnative) species are not the only tree pests of concern when firewood is transported across state lines. Currently, there are many exotic and native species of insects and fungi that should be prevented from moving into uninfested areas of the U.S., including the exotic emerald ash borer (Agrilus planipennis), Asian long-horned beetle (Anoplophora glabripennis), gypsy moth (Lymantria dispar), the pathogen responsible for sudden oak death (Phytophthora ramorum), the native goldspotted oak borer (Agrilus coxal$i s$, and the native pathogen and vector responsible for thousand cankers disease of black walnut (Geosmithia morbida sp. nov. and Pityophthorus juglandis, respectively). Exotic insects most likely introduced on solid wood packing materials (e.g., crating, dunnage, and pallets) in the past include Asian longhorned beetle, at least eight genera of bark beetles and five genera of ambrosia beetles including the banded elm bark beetle (Scolytus schevyrewi), European wood wasp (Sirex noctilio), and at least five genera in the Cerambycidae family (Poland et al. 1998; Haack 2006; Lawrence 2006).

Firewood transport has assisted the dispersal of emerald ash borer (EAB) to new areas of infestation, and camper-assisted dispersal has increased the spread of EAB in the U.S. (Michigan Department of Agriculture 2006; Crocker et al. 2007). Quarantines, aimed at stopping human-assisted movement of ash products (including firewood, logs, and untreated ash lumber) that could harbor EAB to areas outside the infested counties, began in Michigan in 2002 and now include most of Michigan and surrounding states (Haack et al. 2002; USDA APHIS 2009). However, in recent surveys of confiscated or voluntarily surrendered firewood at the Mackinac Bridge connecting the Lower and Upper peninsulas of Michigan live wood-boring insects were found in $23 \%$ of firewood pieces, indicating that the long-distance movement of firewood with insect pests still occurs, even from quarantined areas (Haack et al. 2010). Modeling efforts by BenDor et al. (2006) and Muirhead et al. (2006) implicated the overwhelming importance of human-caused movement of EAB to distant areas along with natural movement of the beetle. Normal insect flight accounted for most of the newly-infested areas near known infestations in Michigan, but outlying infestations were attributed to human dispersal. They also found firewood bundles were brought from EAB-quarantined areas at a rate proportional to the number of campsites (Muirhead et al. 2006).

While there is potential for the movement of fungi via firewood, little research has been conducted on the specifics of this pathway as a risk. The vast biodiversity and unique and poorly understood ecological processes of many fungal species may explain the lack of representation of fungal pathogens in invasion ecology studies (Desprez-Loustau et al. 2007). In addition, 
fungi are easily transported on wood without detection, which make control attempts difficult (Rossman 2001). However, because fungi can survive in dead wood, people may transport viable fungal tree pathogens to new areas via firewood, especially those species with insect vectors. Examples of exotic pathogen transport on firewood include the insect vectors and pathogen of Dutch elm disease (Allen and Humble 2002), the pathogen causing oak wilt (Ceratocystis fagacearum) (Lewis 1987; Juzwik et al. 2008), the vascular fungus and exotic insect vector causing laurel wilt (Raffaelea spp. and Xyleborus glabratus, respectively) (Mayfield 2007), and the pathogen causing sudden oak death (Rizzo and Garbelotto 2003; Cushman and Meentemeyer 2008).

Exotic species can have widespread and long-term deleterious effects on urban and forest ecosystems; examples include chestnut blight (caused by Cryphonectria parasitica), gypsy moth, and Dutch elm disease (Liebhold et al. 1995; Allen and Humble 2002; Lovett et al. 2006; Crocker et al. 2007; Beck et al. 2008). Besides the loss of ecosystem function, wildlife habitat, timber production, or recreational opportunities in naturally forested systems, impacts of invasive tree pests on urban forests include the costs for active management, tree removals/replacements, loss of real estate value, and loss of recreation fee revenues (Liebhold et al. 1995; Pimentel et al. 2005; Sydnor et al. 2007; Beck et al. 2008). As of 2005, Pimentel et al. determined total costs for exotic forest arthropod pest damage and subsequent control were $\$ 2.1$ billion, forest plant pathogen costs were \$2.1 billion, costs of Dutch Elm Disease alone was \$100 million, and gypsy moth control was $\$ 11$ million. The ongoing economic and ecological impacts of EAB damage in Midwestern communities are substantial (Poland and McCullough 2006). EAB is expected to expand to 37.9 million ash trees in urban areas in a 25-state area in the eastern U.S. by 2019 (Kovacs et al. 2010). The cost of treating, removing, and replacing ash trees has been estimated at $\$ 10.7$ billion (Kovacs et al. 2010); however, those costs have been estimated at $\$ 1.8$ and $\$ 7.6$ billion in Ohio communities alone (Sydnor et al. 2007).

It is proposed that camper movement of firewood has the potential to be a high risk pathway of both native and exotic insects and pathogens within and into western states, especially if campers come from infested areas. The objectives of this study were to: 1 ) quantify the proportion and numbers of National and State Park campers in the southern Rocky Mountain region (Arizona, Colorado, Nevada, Utah, and Wyoming) bringing firewood from out of state; 2) determine the state origins of the firewood; and 3) determine other risk factors associated with firewood including wood genera, presence of bark, and presence of previous insect or fungal infestation.

\section{MATERIALS AND METHODS}

\section{Colorado State and Western U.S. National Parks Surveys}

Campers in 15 campgrounds in seven Colorado State Parks were surveyed in 2008 (Figure 1; Table 1). Parks were stratified across Colorado to cover three geographic areas: the eastern plains, the mid-state Front Range areas and areas west of Front Range (Figure 1; Table 1). In 2009, 30 campgrounds were surveyed in 13 National Parks or National Recreation Areas in Arizona, Colorado, Nevada, Utah, and Wyoming (Figure 1; Table 1). In 2007, 2008, and 2009, surveys were conducted in three campgrounds in Rocky Mountain National Park and one campground in the Great Sand Dunes National Park and Preserve each year (repeated surveys). Multiple campgrounds were surveyed in most parks and a campground was defined as having at least 30 camping sites.

A pair of researchers visited campgrounds in June, July, or August in 2007 and 2008 (Colorado State Park surveys and repeated surveys at two National Parks) and between March and August in 2009 (National Park surveys) to ask campers a series of predetermined voluntary questions regarding firewood transport. The number of missed contacts (where campers were not present at occupied campsites) was also recorded. Personal identification information (e.g., names, vehicle license numbers) was not collected so the survey remained anonymous. Data collected included: camper home state, type of camping (recreation vehicle,

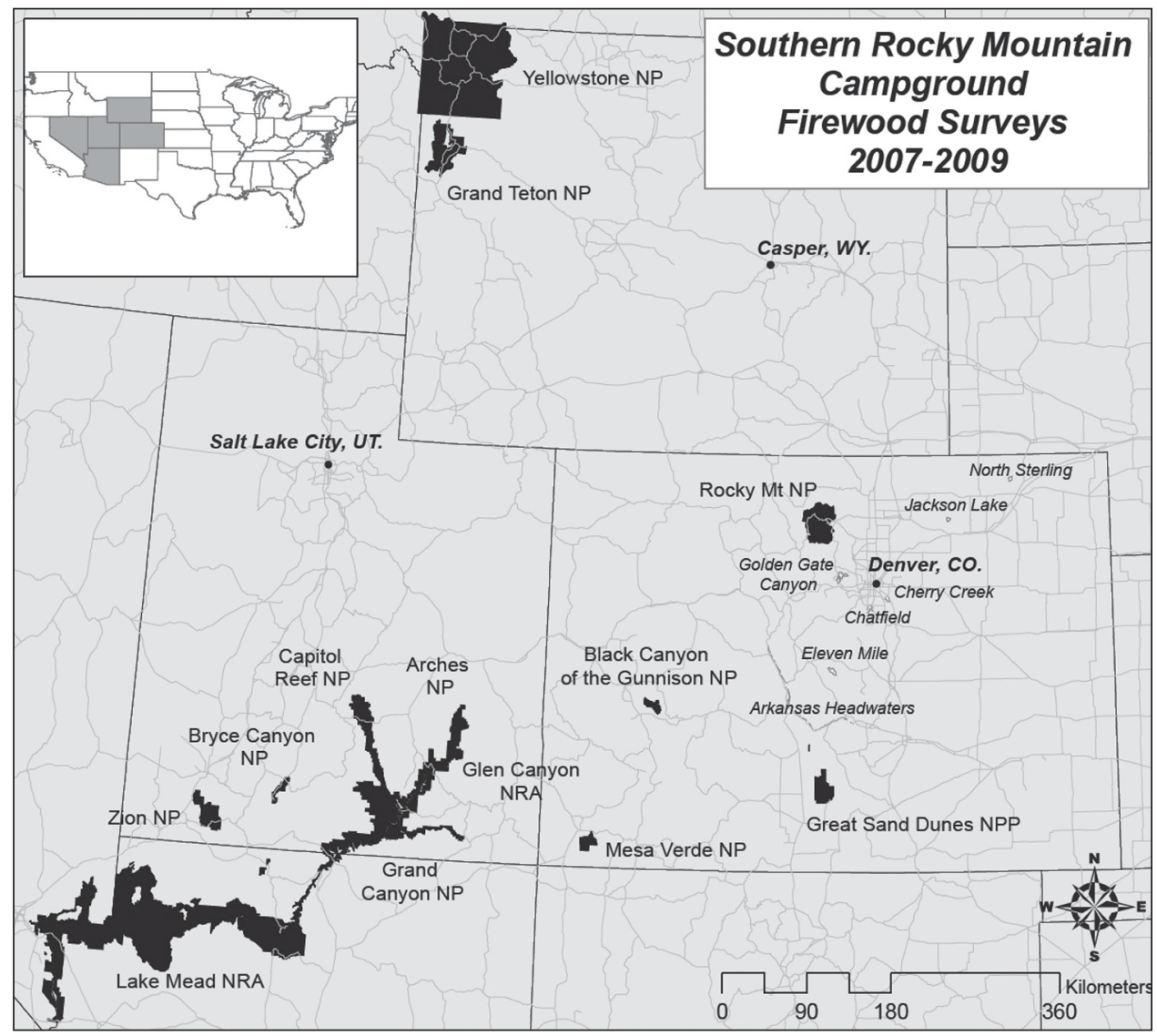

Figure 1. Map of 13 National Parks or Recreation Areas (NPs or NRAs) and seven Colorado State Parks (in italics) surveyed in five states in 2007, 2008, or 2009. 
trailer, etc.), presence of firewood, firewood origin state, firewood source (local vendor in the park, nearby retailer, cut or collected at home, lumber scraps, unknown or other), firewood type [conifer or hardwood and genus/species if possible: pine (Pinus), true fir or Douglas fir (Abies or Psuedotsuga), aspen (Populus tremuloides), oak (Quercus), etc.]. Details on the appearance of the wood were recorded including bark presence and evidence of previous presence of insects and/or stain fungi. The presence of decay fungi was listed as a data collection category but was not easy to confirm in the field and was therefore dropped from the results.

\section{Statistical Analyses}

Frequency counts and percentages were summarized by park and state using the Frequency Procedure in SAS Version 9.2 (SAS Institute, Cary, NC, U.S.) for each response of interest. Chi-square analyses were used to determine if the distributions of camper responses were similar or significantly different across the dependent variable of interest (park states surveyed, recreation type, etc.) at a significance level of $P \leq 0.05$.

Table 1. Camper home states at seven Colorado State Parks in 2008, and 13 western U.S. National Parks in 2009.

\begin{tabular}{|c|c|c|c|c|c|c|}
\hline \multirow[t]{2}{*}{ State/National Park } & \multirow{2}{*}{$\begin{array}{l}2008 \text { overnight } \\
\text { camper totals }^{\mathrm{z}}\end{array}$} & \multirow{2}{*}{$\begin{array}{l}\text { Campers } \\
\text { interviewed }\end{array}$} & \multicolumn{2}{|c|}{ Campers from $(\%)^{\mathrm{y}}$} & \multicolumn{2}{|c|}{ Campers from $(\%)^{y}$} \\
\hline & & & $\begin{array}{l}\text { Park } \\
\text { state }\end{array}$ & $\begin{array}{c}\text { Neighboring } \\
\text { states }\end{array}$ & $\begin{array}{c}\text { Nonneighboring } \\
\text { states }\end{array}$ & $\begin{array}{c}\text { Outside } \\
\text { western U.S. }\end{array}$ \\
\hline \multicolumn{7}{|l|}{ Arizona } \\
\hline Grand Canyon & 208,819 & 111 & 21 & 40 & 39 & 25 \\
\hline Reservation $\operatorname{data}^{\mathrm{x}}(\mathrm{n}=37,812)$ & & & 13 & 29 & 58 & 47 \\
\hline State total/mean ${ }^{w}$ & 208,819 & 111 & 21 & 40 & 39 & 25 \\
\hline \multicolumn{7}{|l|}{ Nevada } \\
\hline Lake Mead & 318,074 & 88 & 36 & 36 & 28 & 14 \\
\hline State total/mean ${ }^{w}$ & 318,074 & 88 & 36 & 36 & 28 & 14 \\
\hline \multicolumn{7}{|l|}{ Colorado } \\
\hline Black Canyon of the Gunnison & 5,420 & 30 & 53 & 4 & 43 & 33 \\
\hline Great Sand Dunes & 13,762 & 51 & 84 & 4 & 12 & 10 \\
\hline $\begin{array}{l}\text { GSDNPP Entrance datav } \\
(\mathrm{n}=8,047)\end{array}$ & & & 65 & 7 & 28 & 25 \\
\hline Mesa Verde & 18,142 & 47 & 17 & 6 & 77 & 53 \\
\hline Reservation data $^{x}(n=20,532)$ & & & 53 & 7 & 40 & 39 \\
\hline State total/mean ${ }^{w}$ & 105,256 & 323 & 38 & 7 & 55 & 49 \\
\hline \multicolumn{7}{|l|}{ Utah } \\
\hline Arches & 19,943 & 18 & 39 & 17 & 44 & 11 \\
\hline Bryce & 31,982 & 81 & 4 & 26 & 70 & 42 \\
\hline Reservation data ${ }^{\mathrm{x}}(\mathrm{n}=2,192)$ & & & 7 & 14 & 79 & 49 \\
\hline Capitol Reef & 13,526 & 40 & 28 & 22 & 50 & 38 \\
\hline Glen Canyon & 383,919 & 95 & 18 & 46 & 36 & 16 \\
\hline Zion & 91,084 & 98 & 6 & 27 & 67 & 21 \\
\hline Reservation $\operatorname{data}^{\mathrm{x}}(\mathrm{n}=16,258)$ & & & 14 & 23 & 63 & 30 \\
\hline State total/mean ${ }^{w}$ & 540,454 & 332 & 16 & 40 & 44 & 19 \\
\hline \multicolumn{7}{|l|}{ Wyoming } \\
\hline Grand Tetons & 103,049 & 391 & 8 & 25 & 67 & 42 \\
\hline Yellowstone & 271,115 & 413 & 3 & 25 & 72 & 42 \\
\hline State total/mean ${ }^{w}$ & 374,164 & 804 & 4 & 25 & 71 & 42 \\
\hline \multicolumn{7}{|l|}{ Colorado State Parks } \\
\hline Eleven-mile & 16,412 & 84 & 74 & 7 & 19 & 15 \\
\hline Arkansas Headwaters & 4,974 & 7 & 57 & 0 & 43 & 33 \\
\hline Chatfield & 25,237 & 77 & 56 & 5 & 39 & 19 \\
\hline Cherry Creek & 19,154 & 97 & 49 & 2 & 49 & 39 \\
\hline Golden Gate Canyon & 14,681 & 64 & 80 & 2 & 18 & 13 \\
\hline Jackson Lake & 12,813 & 19 & 95 & 0 & 5 & 0 \\
\hline North Sterling & 5,202 & 14 & 93 & 0 & 7 & 7 \\
\hline State Park grand total/mean $w$ & 98,473 & 362 & 68 & 3 & 29 & 19 \\
\hline
\end{tabular}

${ }^{\mathrm{z}}$ Campers = camper groups $=$ total overnight visitors per park in 2008 (NPS 2008), divided by average number of persons-per-vehicle.

${ }^{y}$ Camper weighted data are given for state mean proportions: weighting factor was computed from total 2008 campers at each park divided by the number of campers interviewed (see METHODS).

${ }^{x}$ Campground reservation data for January through December 2008 was derived from the National Recreation Reservation System accessible through recreation.gov (provided by APHIS, see METHODS).

w The National Park camper home states percentages (proportion of park state, next state, or nonneighboring state) was significantly different among the five states sur-

veyed and the State Park camper home states percentages were significantly different among the parks surveyed based on $\chi^{2}$ tests (both $\mathrm{p}<0.0001$ ).

${ }^{\vee}$ Great Sand Dunes National Park and Preserve (GSDNPP) collected camper home state data from January through December 2008 (see METHODS). 


\section{Weighted frequencies using park visitor statistics}

In order to obtain estimates that represent total campers for all parks in the study and avoid disproportionately skewing results by simply combining proportions of camper responses from smaller parks with very large parks, response frequencies and individual camper data were weighted. Each park weighting factor was calculated as total camper groups in 2008 (National Park Service 2008) divided by the number of camper groups interviewed in 2008 or 2009. Total camper groups were calculated by dividing the number of annual overnight campers by the individual or averaged persons-per-vehicle multiplier that each park uses to estimate total visitors from the number of campsites occupied or camping permits sold (NPS 2008). Weighting factors were used in all analyses. For example, since there were 413 campers surveyed in Yellowstone NP and the total number of annual camper groups was estimated at 271,115 , each surveyed camper group was weighted by $656(271,115 / 413)$. Total camper groups were used in the risk analyses as those data best represent the survey methods (one to several individuals per campsite were interviewed) (Table 1). The term "campers" throughout these analyses refers to the number of camper groups (i.e., groups of people at one campsite) at parks. State park visitor statistics for the seven parks surveyed were obtained directly from Colorado State Parks (pers. comm. Matt Schulz, Forest Management and GIS Coordinator 2010), and the weighting factors represent the number of campsite permits sold in 2008 divided by the number of people surveyed at each park. If campers had firewood from two state origins or wood sources the weighted counts were added together.

\section{Additional data on park visitation}

Two sources provided additional data on park visitation independent of NPS statistics: the Great Sand Dunes National Park and Preserve (GSDNPP), which collected camper home state data throughout 2008 (data on file, pers. comm. Phyllis Pineda-Bovin, Park Biologist), and the USDA Animal and Plant Health Inspection Service (APHIS), which provided reservation data made available from a query of the National Recreation Reservation Service for several parks in 2008 (data on file, pers. comm. Judith E. Pasek, Senior Regional Program Manager, Data \& Risk Management, USDA, APHIS). The personal firewood surveys were limited to only one to three days per each park, and these yearly, more complete reservation data provided by GSDNPP and APHIS were used to compare and confirm the proportions of visitors from various locations to the weighted proportions.

\section{RESULTS}

\section{State and National Park Camper Populations}

Campers at 15 campgrounds in seven Colorado State Parks were surveyed between June and August 2008 (Figure 1; Table 1). Most surveys were conducted in person, but four state parks also handed out paper surveys over two-week periods to increase the sample sizes $(n=126$ paper survey responses). Of the 608 attempted personal campsite surveys at Colorado State Parks, 368 campsites $(61 \%)$ were empty and 62 sites $(10 \%)$ were occupied but no campers were present (missed contacts). In most cases at State Parks, the vehicle license plate state of missed contacts were recorded so their home state was known without a survey contact $(\mathrm{n}=59)$. A total 362 campers (or their vehicle license plate state source) represented 30 states and four countries, of which 303 (177 personal and 126 paper survey responses) provided information on firewood presence and origins (Table 2; Table 3). Paper surveys did not ask respondent what type of camping vehicle they had so those data are missing in some state park surveys (Table 2). Of the 303 state park campers interviewed, $66 \%$ had firewood as a weighted proportion $(n=193)$ (Table 3$)$. Thirteen National Parks were visited between March and August 2009 and 30 campgrounds within these parks were surveyed (Figure 1; Table 1). Results indicated that 4,522 campsites were visited and $28 \%$ were empty, $35 \%$ of the sites were occupied but no one was present, and $37 \%$ ( $n=1,658$ sites) had campers present (Table 1). National Park campers represented 46 states and 20 countries, and $60 \%(n=1,116)$ had firewood as a weighted proportion (Table 3$)$.

The percentage of campers visiting Colorado State Parks who lived in Colorado was high, at 68\% (Table 1). Many more campers at State Parks were from nonneighboring states (29\%) than neighboring states (3\%) (Table 1). The percentage of National Park campers who lived in the home state of the park ranged from three percent at Yellowstone (Wyoming) to $84 \%$ at the Great Sand Dunes (Colorado), with an overall mean of $20 \%$ (Table 1). Campers from neighboring states ranged from $4 \%$ at the Black Canyon of the Gunnison (Colorado) and Great Sand Dunes to $46 \%$ at Glen Canyon (Utah), with an overall mean of 33\% (Table 1). Campers coming from nonneighboring states ranged from $12 \%$ at the Great Sand Dunes to $77 \%$ at Mesa Verde (Colorado), with an overall mean of $47 \%$ (Table 1). The distribution of camper home states (park, neighboring, or nonneighboring) was significantly different between the totals of the five states (for national park surveys) or between state parks (for Colorado State Park surveys) based on $\chi^{2}$ tests (both $\mathrm{p}<0.0001$ ) (Table 1 ). The proportion of campers visiting from outside the western United States (east of New Mexico, Colorado, Wyoming, and Montana) varied by park and state. Twenty-six percent of National Park campers came from outside the western U.S., and Wyoming and Colorado had the highest proportions of nonwestern campers ( $42 \%$ and $49 \%$, respectively) (Table 1). The two National Parks with the highest percentages of nonwestern visitors were Mesa Verde and Rocky Mountain in Colorado (53\% and 57\%, respectively) (Table 1). In Colorado State Parks, the overall proportion of campers from nonwestern states was $19 \%$ with individual parks ranging from zero to $39 \%$ (Table 1).

\section{Collaborative camper and reservation data}

At parks for which reservation data were available, consistencies were found between year-round reservation data and the one-time visit to survey parks (Table 1). At the two Utah National Parks where data were available, the highest proportions of campers were from nonneighboring states and the lowest proportions were from the park state in both datasets (Table 1). There were some differences at Rocky Mountain NP, where most reservations were made by campers in the park state $(53 \%)$, surveys indicated that most campers were from nonneighboring states $(58 \%)$ (Table 1). The largest proportion of reservations at Grand Canyon were made from nonneighboring states $(58 \%)$, while study data indicated that similar proportions of campers came from neighboring (40\%) and nonneighboring (39\%) states (Table 1). The 2008 Great Sand Dunes year-round data had similar proportions to the camper surveys: $65 \%$ of their campers came from the park state (Colorado), $7 \%$ from neighboring states, and 28\% from nonneighboring states (25\% from western U.S. overall) (Table 1$)$. 
Table 2. Number and percentages of camper recreation types with firewood at seven Colorado State Parks in 2008 , and 13 western U.S. National Parks in 2009.

\begin{tabular}{|c|c|c|c|c|c|c|c|c|}
\hline \multirow[t]{3}{*}{ Recreation Type } & \multicolumn{4}{|c|}{ Colorado State Parks 2008 } & \multicolumn{4}{|c|}{ National Parks 2009} \\
\hline & \multicolumn{2}{|c|}{ Campers } & \multicolumn{2}{|c|}{ Campers with firewood } & \multicolumn{2}{|c|}{ Campers } & \multicolumn{2}{|c|}{ Campers with firewood } \\
\hline & $\#$ & $\%^{y}$ & \# & $\%^{\mathrm{yx}}$ & \# & $\%^{y}$ & $\#$ & $\% \%^{\mathrm{yx}}$ \\
\hline Trailer & 77 & 32 & 31 & 50 & 255 & 18 & 175 & 64 \\
\hline Tent Trailer & 20 & 8 & 10 & 68 & 144 & 7 & 104 & 61 \\
\hline Tent & 54 & 25 & 35 & 85 & 940 & 49 & 661 & 67 \\
\hline Other & 2 & 1 & 1 & 37 & 53 & 4 & 29 & 48 \\
\hline
\end{tabular}

${ }^{2}$ Colorado State Park surveys included paper surveys handed out in addition to personal surveys. Paper surveys did not ask campers what type of camping vehicle they had so sample size is only relevant to personal surveys $(n=238)$. Percentages and weights adjusted accordingly.

y Camper weighted data given for recreation type mean proportions: weighting factor was computed from total 2008 campers per park divided by the number of campers interviewed (see methods section).

${ }^{x}$ The percent of campers with firewood was significantly different among the six recreation types surveyed based on a $\chi^{2}$ test at both State and National Parks (both $\left.\mathrm{p}<0.0001\right)$

Table 3. State origin of firewood and home state of campers at seven Colorado State Parks in 2008, and 13 western U.S. National Parks in 2009.

\begin{tabular}{|c|c|c|c|c|c|c|c|}
\hline \multirow{2}{*}{$\begin{array}{l}\text { State origin of firewood } \\
\text { (proximity to park state) }\end{array}$} & \multicolumn{2}{|l|}{ Mean } & \multicolumn{3}{|c|}{ Campers from } & \multicolumn{2}{|c|}{ Campers from } \\
\hline & $\begin{array}{c}\text { Campers with } \\
\text { firewood } \\
(\%)^{2} \\
\end{array}$ & $\begin{array}{l}\text { Firewood } \\
(\%)^{z}\end{array}$ & $\begin{array}{l}\text { Park state } \\
(\%)^{\mathrm{z}}\end{array}$ & $\begin{array}{l}\text { Neighboring } \\
\text { states }(\%)^{2}\end{array}$ & $\begin{array}{l}\text { Nonneighboring } \\
\text { states }(\%)^{\mathrm{z}}\end{array}$ & $\begin{array}{c}\text { Western states } \\
(\%)^{\mathrm{z}}\end{array}$ & 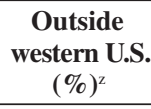 \\
\hline \multicolumn{8}{|l|}{ Arizona (Grand Canyon), $\mathrm{n}=83$} \\
\hline Park state & 80 & 72 & 28 & 35 & 37 & 37 & 63 \\
\hline Out-of-state & 29 & 27 & 14 & 50 & 36 & 55 & 45 \\
\hline Outside western U.S. & 5 & 5 & 50 & 0 & 50 & 50 & 50 \\
\hline \multicolumn{8}{|l|}{ Nevada (Lake Mead), $\mathrm{n}=44$} \\
\hline Park state & 57 & 55 & 88 & 4 & 8 & 96 & 4 \\
\hline Out-of-state & 48 & 45 & 10 & 40 & 50 & 40 & 60 \\
\hline Outside western U.S. & 9 & 9 & 0 & 0 & 100 & 0 & 100 \\
\hline \multicolumn{8}{|l|}{ Colorado, $\mathrm{n}=244$} \\
\hline Park state & 92 & 88 & 47 & 6 & 47 & 54 & 46 \\
\hline Out-of-state & 10 & 10 & 14 & 22 & 64 & 59 & 41 \\
\hline Outside western U.S. & 4 & 4 & 15 & 12 & 73 & 15 & 85 \\
\hline \multicolumn{8}{|l|}{ Utah, $\mathrm{n}=192$} \\
\hline Park state & 41 & 41 & 32 & 23 & 45 & 45 & 55 \\
\hline Out-of-state & 58 & 57 & 18 & 50 & 32 & 34 & 66 \\
\hline Outside western U.S. & 5 & 5 & 8 & 6 & 86 & 6 & 94 \\
\hline \multicolumn{8}{|l|}{ Wyoming, $\mathrm{n}=605$} \\
\hline Park state & 77 & 73 & 5 & 21 & 75 & 39 & 61 \\
\hline Out-of-state & 27 & 26 & 1 & 46 & 53 & 61 & 39 \\
\hline Outside western U.S. & 3 & 3 & 0 & 20 & 80 & 37 & 63 \\
\hline \multicolumn{8}{|c|}{ National Parks grand totals, $n=1,168$} \\
\hline Park state & $64(587,119)^{y}$ & $62(599,072)^{y}$ & )$^{y} \quad 31$ & 20 & 49 & 50 & 50 \\
\hline Out-of-state & $39(329,919)^{y}$ & $37(360,046)^{y}$ & )$^{y} \quad 12$ & 47 & 41 & 44 & 56 \\
\hline Outside western U.S. & $5(45,999)^{y}$ & $5(47,352)^{y}$ & 11 & 6 & 83 & 17 & 83 \\
\hline Overall home state of National & $(929,226)^{y}$ & $(971,307)^{\mathrm{y}}$ & 24 & 30 & 46 & 48 & \\
\hline $\begin{array}{l}\text { Park campers with firewood } \\
\text { (weighted counts) }\end{array}$ & & & $(233,945)^{y}$ & $(288,266)^{y}$ & $(449,096)^{y}$ & $(461,805)^{\mathrm{y}}$ & $(509,502)^{y}$ \\
\hline \multicolumn{8}{|c|}{ Colorado State Parks grand totals, $n=193$} \\
\hline Park state & $96(52,189)^{y}$ & $96(52,189)^{y}$ & 78 & 2 & 20 & 82 & 18 \\
\hline Out-of-state & $4(2,358)^{y}$ & $4(2,358)^{y}$ & 0 & 10 & 90 & 52 & 48 \\
\hline Outside western U.S. & $2(1,126)^{y}$ & $2(1,126)^{y}$ & 0 & 0 & 100 & 0 & 100 \\
\hline Overall home state of State Park & $(54,547)^{\mathrm{y}}$ & $(54,547)^{y}$ & & & & & 19 \\
\hline $\begin{array}{l}\text { campers with firewood } \\
\text { (weighted counts) }\end{array}$ & & & $(40,482)^{y}$ & $(1,534)^{y}$ & $(12,531)^{y}$ & $(44,333)^{y}$ & $(10,409)^{y}$ \\
\hline
\end{tabular}




\section{Camper recreation types}

At Colorado State Parks, the type of recreation vehicle campers used varied $[\mathrm{n}=238$ (only personal surveys asked for this information) and then weighted by 2008 camper counts]. Recreational vehicle (RV) users were the most common $(34 \%)$ camping type and campers with tents $(85 \%)$ were the most likely to have firewood (Table 2). At National Parks, the camping/vehicle type proportions were different than State Parks, with tent-camping the most common (49\%), and again campers with tents $(67 \%)$ were most likely to have firewood (Table 2).

\section{State Origins of Firewood}

Proportions of campers bringing firewood from out-of-state origins varied between parks and states. At Colorado State Parks, only four percent of campers brought firewood from outside of the state, or approximately 2,358 campers per year (Table 3; Figure 2a). Of the four percent of Colorado State Park campers with out-of-state wood, $10 \%$ were from neighboring states and $90 \%$ from nonneighboring states (Table 3; Figure 2a). The overall proportion of National Park campers who brought firewood from out-of-state origins to the 13 National Park campgrounds was $39 \%$ (37\% of all firewood was out-ofstate), or, when weighted with National Park visitor statistics, 329,919 campers in one year. Some campers had wood from two state origins, so the risk analysis indicated 360,046 out-ofstate wood sources were brought by 329,919 campers in one year (Table 3; Figure 2a). The percentage of campers bringing
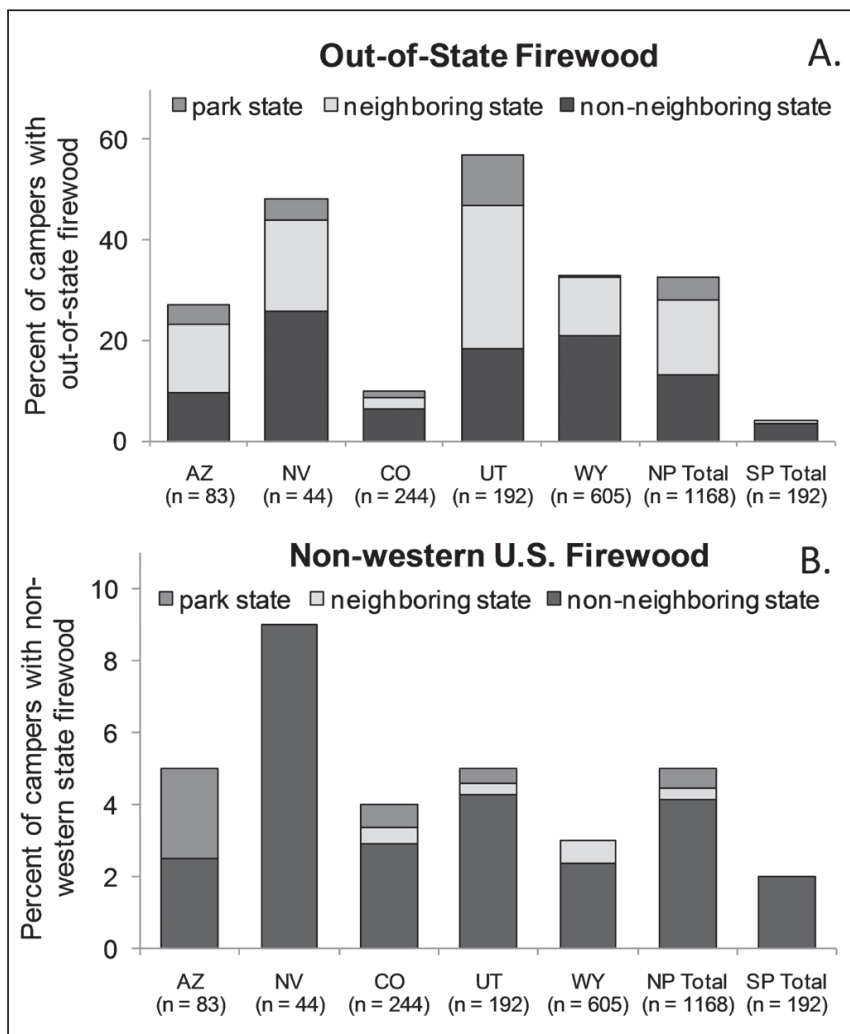

Figure 2. Home states (park state, neighboring state or nonneighboring state) of campers with firewood from out-of-state (a), and from nonwestern United State origins (b), at seven Colorado State Parks in 2008 and 13 western U.S. National Parks in 2009. firewood from out of state ranged from $10 \%$ to $58 \%$ among the states surveyed (Table 3 ). Of campers with out-of-state wood, $12 \%$ came from the park state, $47 \%$ from a neighboring state, and $41 \%$ from a nonneighboring state (Table 3; Figure 2a).

The proportion of firewood from outside the western United States (east of NM, CO, WY, and MT, or non-U.S. sources) varied by state, ranging from three percent in Wyoming to nine percent in Nevada (Table 3; Figure 2b). The National Park mean of five percent, combined with 2008 NPS visitor statistics, indicated that approximately 46,000 campers brought firewood to these parks from outside the western United States in one year (Table 3; Figure 2b). Overall, $83 \%$ of firewood from outside the western United States was brought by campers who lived outside the western U.S. (state means ranged from $50 \%$ in Arizona, to $100 \%$ in Nevada) (Table 3; Figure 2b). Only two percent of Colorado State Park campers brought wood from nonwestern states; this equated to a risk of 1,126 campers in one year (Table 3; Figure $2 b$ ).

The repeated yearly surveys in 2007, 2008, and 2009 at the Great Sand Dunes National Park and Preserve and Rocky Mountain National Park of Colorado indicate similar proportions of campers brought out-of-state firewood in each year surveyed: $5 \%$ to $12 \%$ at Rocky Mountain, and $6 \%$ to $14 \%$ at Great Sand Dunes (Figure 3a). The percentages of campers from Colorado, neighboring states and nonneighboring states with out-of-state firewood remained fairly constant over the three years (Figure 3a).

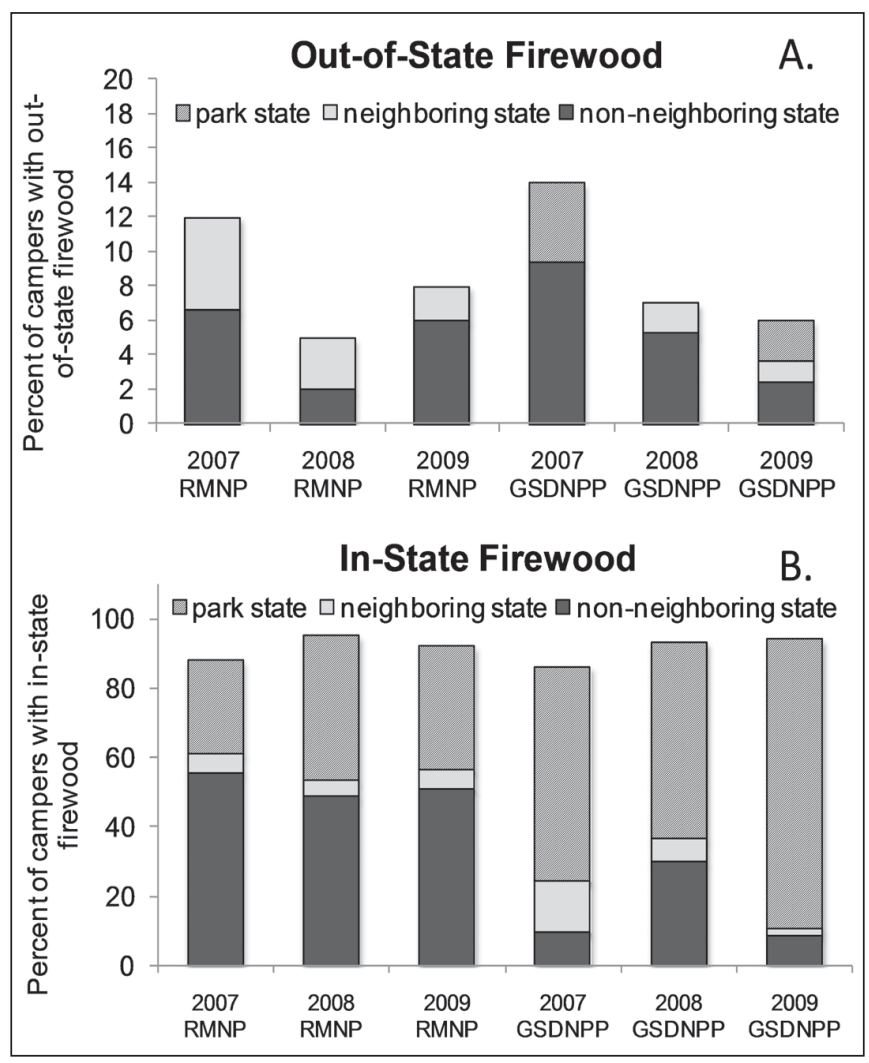

Figure 3. Home states (park state, neighboring state or nonneighboring state) of campers with firewood from out-of-state (a), and firewood from in-state (b), at Rocky Mountain (RMNP) and Great Sand Dunes (GSDNPP) National Parks, Colorado, over three years of surveys $(2007,2008$, and 2009$)$. 


\section{Sources of Firewood}

The sources from which campers obtained their firewood were not skewed to any particular outlet. At Colorado State Parks, $30 \%$ of campers obtained wood at locations within the park (usually park or marina vendors), $28 \%$ of campers bought wood at retail locations outside the park, $15 \%$ of the wood was cut or collected at home, $10 \%$ was scrap lumber $(2 \times 4 \mathrm{~s}$, old cabinets, etc.), $5 \%$ was from other sources (cut or collected from another area), and $12 \%$ was from an unknown source (no one at the campsite knew the firewood source) (Table 4). At National Parks, 32\% of campers purchased firewood inside the park, $25 \%$ purchased wood at retail locations outside the park, $17 \%$ of the wood was cut or collected at home, $12 \%$ was scrap lumber, $14 \%$ was from other sources, and $0.1 \%$ unknown (Table 4 ).

\section{Firewood Type and Condition, and Other Risk Factors}

Conifer wood was the most prevalent firewood type at both State $(46 \%)$ and National $(66 \%)$ park campgrounds, while pure hardwood was noted $21 \%$ of the time at National Parks and eight percent of the time at State Parks (Table 5). Bark was attached to firewood $64 \%$ of the time at National Parks and $74 \%$ of the time at Colorado State Parks (Table 5). The type of firewood varied by state, but pine species were the most abundant firewood in all states $(61 \%$ in National Parks and $42 \%$ in State Parks) (Table $5)$. Only $31 \%$ of firewood was pine in Nevada parks, while Wyoming parks had $83 \%$ pine (Table 5). In Wyoming and Colorado, $89 \%-91 \%$ of pine firewood had bark attached, while only $22 \%$ of Arizona pine had bark present (Table 5). Other items of note are that "other" hardwood species had bark attached $89 \%$ and $58 \%$ of the time at State and National Parks, respectively, and that oak and aspen were a proportion of the total firewood species at national parks $(4 \%-5 \%)$ in every state (Table 5). Ash firewood was a small proportion $(<2 \%)$ in three of five states (Table 5).

The presence of signs and symptoms of previous insect and fungal infestations noted on firewood was expected because most firewood is derived from dead trees or material not used in the processing of logs into wood products. In National Parks, approximately $53 \%$ of the wood had evidence of previous infestation by bark beetles or wood borers and $39 \%$ had stain fungi apparent (Table 6). The condition of firewood ranged greatly by state; only $15 \%$ of firewood in Arizona had evidence of previous insect activity while $73 \%$ of Colorado firewood did (Table 6). Campers in Colorado State Parks had high proportions of previously infested wood as well; $71 \%$ of wood had evidence of insects and $79 \%$ had stain fungi (Table 6). In National Parks, firewood from out of state had $18 \%$ less occurrence of bark beetle and/or wood borers and $32 \%$ less occurrence of fungal evidence than wood from the park state (Table 6). The study authors were not able to examine any out-of-state wood in Colorado State Parks to confirm previous insect or fungal activity (Table 6).

\section{DISCUSSION}

\section{Camper Populations}

The western United States contains many unique natural areas that attract visitors from all over the nation and the world. Surveys indicated that $80 \%$ of National Park campers surveyed were from out of state, and online reservation data from four matching parks confirmed reservations made by out-of-state visitors were $79 \%$ of the total (Table 1). The increasing introduction rates of non-indigenous species are often cited as the result of trends in global commerce or by human mediated transport, and these introductions can be devastating for urban or naturally forested areas (Allen and Humble 2002; Tkacz 2002; Haack 2006; Cushman and Meentemeyer 2008). Based on some assumptions of camper behavior-including vehicular travel along major roads and highways, multiple stops, and traveling with a high volume of associated goods from home (including food, firewood, and other essentials) — the study authors hypothesize that the sheer numbers of National and State Park campers crossing state borders may be a major pathway of pest transport based on the amount of campers moving untreated, raw wood.

\section{Camper-Mediated Firewood Transport}

Untreated, nonmanufactured wood is known to be a pathway for moving pests into new environments (Tkacz 2002; Haack 2006; Haack et al. 2010). The regulations associated with treating imported raw wood products recognize the risks associated with pest transport via untreated wood (NPB 2010). It has been determined that campers move firewood across state borders and over long distances to new areas of the United States (Table 3 ). Based on this information, there is strong potential for the movement of firewood to be a high-risk pathway for moving tree pests. The potential risk of approximately 330,000 National Park campers bringing untreated firewood from other states into the 13 National Parks surveyed indicates the possibility of moving insects and fungi into new areas of the U.S. (Table 3). Forty-one percent of campers with out-of-state firewood were from nonneighboring states and five percent of campers brought firewood from east of the continental divide or from outside of the country, indicating that long-distance transportation of untreated wood by campers occurs (Table 3). As of July 8, 2010, EAB had been found in 14 U.S. states and Canada, and as far west as Missouri and Minnesota (USDA APHIS 2010). Although federal and state quarantines have been implemented in most infested states, firewood was brought to Colorado State and National Parks from 25 states across the nation (Alaska to New Hampshire to Louisiana) and several campers brought wood from EAB quarantine states (Illinois, Indiana, Minnesota, Pennsylvania, and West Virginia). Although highly publicized quarantines in Midwest states like Michigan occur, recent detailed inspections of firewood in Michigan confirmed that firewood was still being transported, most likely from quarantined counties throughout Michigan and surrounding states, and 23\% of the wood contained live wood-boring insects (Haack et al. 2010).

\section{Risk Factors Associated with Firewood}

The risk of firewood as a transportation pathway will vary depending on whether bark is attached, if it is in a specific genus, where it was purchased, where it is burned, if it has evidence of previous insect or fungal infestation, or if a suitable host is near the campground. Bark is not readily removed from all firewood pieces and the presence of bark increases the survival ability of wood pests and may attract secondary pests to the wood (Haack and Petrice 2007; Petrice and Haack 2007). There are also risks of Cerambycidae and Scolytinae infesting logs with residual bark 
even after heat treatment, although beetles are not known to reinfest logs that were both heat treated and de-barked (Dunbar and Stephens 1974; McCullough et al. 2007; Petrice and Haack 2007; Haack and Petrice 2009). Over all the National Parks surveyed, $64 \%$ of firewood contained intact bark, which may provide loca- tions for bark-inhabiting bark beetles, wood borers, and canker fungi (Haack 2006; Haack and Petrice 2007; Petrice and Haack 2007; Haack and Petrice 2009; Haack et al. 2010). The commonly used treatments of splitting, drying, and storing for one year may not be sufficient in eliminating insects from firewood and a com-

Table 4. Firewood source and home state of campers at seven Colorado State Parks in 2008 , and 13 western U.S. National Parks in 2009.

\begin{tabular}{|c|c|c|c|c|}
\hline \multirow[t]{2}{*}{ Firewood Source ${ }^{2}$} & \multicolumn{4}{|l|}{ Campers from } \\
\hline & all states $(\%)$ & park state $(\%)$ & $\begin{array}{c}\text { neighboring } \\
\text { states }(\%)\end{array}$ & $\begin{array}{c}\text { nonneighboring } \\
\text { states }(\%)\end{array}$ \\
\hline \multicolumn{5}{|l|}{ Arizona, $\mathrm{n}=85$} \\
\hline Outside park & 24 & 14 & 32 & 20 \\
\hline Inside park & 48 & 38 & 47 & 57 \\
\hline From home & 15 & 29 & 15 & 7 \\
\hline Scrap lumber & 7 & 14 & 6 & 3 \\
\hline Other & 6 & 5 & 0 & 13 \\
\hline Unknown & 0 & 0 & 0 & 0 \\
\hline \multicolumn{5}{|l|}{ Nevada, $n=43$} \\
\hline Outside park & 19 & 22 & 11 & 18 \\
\hline Inside park & 5 & 9 & 0 & 0 \\
\hline From home & 26 & 26 & 22 & 27 \\
\hline Scrap lumber & 30 & 13 & 56 & 45 \\
\hline Other & 21 & 30 & 11 & 9 \\
\hline Unknown & 0 & 0 & 0 & 0 \\
\hline \multicolumn{5}{|c|}{ Colorado (national parks), $\mathrm{n}=277$} \\
\hline Outside park & 26 & 32 & 16 & 21 \\
\hline Inside park & 51 & 36 & 56 & 65 \\
\hline From home & 9 & 14 & 9 & 5 \\
\hline Scrap lumber & 7 & 11 & 14 & 3 \\
\hline Other & 6 & 7 & 5 & 6 \\
\hline Unknown & 0.2 & 0 & 0 & 0 \\
\hline \multicolumn{5}{|l|}{ Utah, $n=209$} \\
\hline Outside park & 42 & 31 & 40 & 53 \\
\hline Inside park & 14 & 15 & 16 & 11 \\
\hline From home & 25 & 18 & 22 & 32 \\
\hline Scrap lumber & 14 & 28 & 16 & 2 \\
\hline Other & 5 & 7 & 6 & 3 \\
\hline Unknown & 0 & 0 & 0 & 0 \\
\hline \multicolumn{5}{|l|}{ Wyoming, $\mathrm{n}=640$} \\
\hline Outside park & 12 & 14 & 13 & 12 \\
\hline Inside park & 50 & 36 & 38 & 55 \\
\hline From home & 9 & 9 & 17 & 5 \\
\hline Scrap lumber & 5 & 6 & 10 & 3 \\
\hline Other & 24 & 36 & 22 & 25 \\
\hline Unknown & 0.3 & 0 & 0 & 0 \\
\hline \multicolumn{5}{|c|}{ National Parks grand total, $\mathrm{n}=1254$} \\
\hline Outside park & 25 & 25 & 27 & 24 \\
\hline Inside park & 32 & 21 & 28 & 41 \\
\hline From home & 17 & 21 & 19 & 14 \\
\hline Scrap lumber & 12 & 17 & 16 & 6 \\
\hline Other & 14 & 16 & 10 & 15 \\
\hline Unknown & 0.1 & 0.1 & 0 & 0.2 \\
\hline \multicolumn{5}{|c|}{ Colorado State Parks grand total, $\mathrm{n}=192$} \\
\hline Outside park & 28 & 29 & 40 & 21 \\
\hline Inside park & 30 & 29 & 38 & 32 \\
\hline From home & 15 & 18 & 21 & 3 \\
\hline Scrap lumber & 10 & 12 & 0 & 8 \\
\hline Other & 5 & 6 & 0 & 5 \\
\hline Unknown & 12 & 6 & 0 & 31 \\
\hline
\end{tabular}

${ }^{\mathrm{z}} \mathrm{n}=$ wood sources (if more than one wood source was given each was counted)

Note: Camper weighted data given for state mean proportions: weighting factor was computed from total 2008 campers per park divided by the number of campers interviewed (see METHODS). 
Table 5. Percent of all wood types noted per state at 13 western U.S. National Parks in 2009, and seven Colorado State Parks in 2008.

\begin{tabular}{|c|c|c|c|c|c|c|c|c|c|c|c|c|c|c|}
\hline \multirow[t]{2}{*}{ Wood type } & \multicolumn{2}{|c|}{ Arizona } & \multicolumn{2}{|c|}{ Colorado } & \multicolumn{2}{|c|}{ Nevada } & \multicolumn{2}{|c|}{ Utah } & \multicolumn{2}{|c|}{ Wyoming } & \multicolumn{2}{|c|}{ National Park Total } & \multicolumn{2}{|c|}{ CO State Park Total } \\
\hline & $\begin{array}{c}\text { All } \\
\text { wood } \\
(\%)\end{array}$ & $\begin{array}{l}\text { With } \\
\text { bark } \\
(\%)\end{array}$ & $\begin{array}{c}\text { All } \\
\text { wood } \\
(\%)\end{array}$ & $\begin{array}{c}\text { With } \\
\text { bark } \\
(\%)\end{array}$ & $\begin{array}{c}\text { All } \\
\text { wood } \\
(\%)\end{array}$ & $\begin{array}{l}\text { With } \\
\text { bark } \\
(\%)\end{array}$ & $\begin{array}{c}\text { All } \\
\text { wood } \\
(\%)\end{array}$ & $\begin{array}{c}\text { With } \\
\text { bark } \\
(\%)\end{array}$ & $\begin{array}{c}\text { All } \\
\text { wood } \\
(\%)\end{array}$ & $\begin{array}{c}\text { With } \\
\text { bark } \\
(\%)\end{array}$ & $\begin{array}{l}\text { All } \\
\text { wood } \\
(\%)\end{array}$ & $\begin{array}{l}\text { With } \\
\text { bark } \\
(\%)\end{array}$ & $\begin{array}{l}\text { All } \\
\text { wood } \\
(\%)\end{array}$ & $\begin{array}{l}\text { With } \\
\text { bark } \\
(\%)\end{array}$ \\
\hline Pine & 65 & 22 & 67 & 91 & 31 & 71 & 55 & 67 & 83 & 89 & 61 & 71 & 42 & 85 \\
\hline Fir $\left(\right.$ inc. DF) ${ }^{\mathrm{z}}$ & 3 & 33 & 1 & 100 & 2 & 0 & 3 & 58 & 1 & 58 & 2 & 44 & 2 & 100 \\
\hline Other conifer & 2 & 100 & 1 & 79 & 6 & 67 & 5 & 72 & 1 & 50 & 3 & 72 & 2 & 24 \\
\hline Oak & 6 & 40 & 3 & 84 & 2 & 100 & 6 & 77 & 2 & 71 & 4 & 70 & 0 & - \\
\hline Ash & 0 & 0 & 0.4 & 100 & 2 & 0 & 0 & 0 & 0.1 & 100 & 0.4 & 14 & 0 & - \\
\hline Aspen & 1 & 100 & 17 & 92 & 4 & 100 & 6 & 93 & 3 & 74 & 5 & 91 & 1 & 100 \\
\hline Other hardwood & 11 & 40 & 5 & 52 & 28 & 47 & 13 & 79 & 5 & 65 & 12 & 58 & 7 & 89 \\
\hline Unknown & 11 & 30 & 5 & 46 & 26 & 21 & 12 & 16 & 5 & 33 & 12 & 23 & 46 & 62 \\
\hline Total & 100 & 29 & 100 & 87 & 100 & 50 & 100 & 64 & 100 & 84 & 100 & 64 & 100 & 74 \\
\hline
\end{tabular}

${ }^{\mathrm{z}}$ Category includes true firs and Douglas-fir (DF)

Note: Camper weighted data are given for mean proportions: weighting factor was computed from total 2008 campers at each park divided by the number of campers interviewed (see methods section).

Table 6. Evidence of previous insect evidence and fungal infestation of firewood at seven Colorado State Parks in 2008, and 13 western U.S. National Parks in 2009.

\begin{tabular}{|c|c|c|c|}
\hline Presence of previous infestation & $\begin{array}{l}\text { Firewood from } \\
\text { All states }(\%)\end{array}$ & Park state $(\%)$ & Out-of-state $(\%)$ \\
\hline \multicolumn{4}{|l|}{ Arizona, $\mathrm{n}=671$} \\
\hline Bark beetles & 10 & 4 & 33 \\
\hline Wood borers & 7 & 6 & 13 \\
\hline Stain fungi & 66 & 76 & 33 \\
\hline Insects (beetles \& borers) & 15 & 8 & 40 \\
\hline \multicolumn{4}{|l|}{ Nevada, $n=36$} \\
\hline Bark beetles & 6 & 5 & 7 \\
\hline Wood borers & 19 & 19 & 20 \\
\hline Stain fungi & 8 & 14 & 0 \\
\hline Insects (beetles \& borers) & 19 & 19 & 20 \\
\hline \multicolumn{4}{|l|}{ Colorado, $\mathrm{n}=225$} \\
\hline Bark beetles & 70 & 74 & 32 \\
\hline Wood borers & 67 & 69 & 37 \\
\hline Stain fungi & 64 & 67 & 32 \\
\hline Insects (beetles \& borers) & 73 & 77 & 37 \\
\hline \multicolumn{4}{|l|}{ Utah, $\mathrm{n}=164$} \\
\hline Bark beetles & 47 & 66 & 33 \\
\hline Wood borers & 33 & 47 & 24 \\
\hline Stain fungi & 9 & 11 & 8 \\
\hline Insects (beetles \& borers) & 57 & 79 & 42 \\
\hline \multicolumn{4}{|l|}{ Wyoming, $\mathrm{n}=562$} \\
\hline Bark beetles & 72 & 81 & 44 \\
\hline Wood borers & 66 & 72 & 48 \\
\hline Stain fungi & 64 & 77 & 25 \\
\hline Insects (beetles and borers) & 76 & 82 & 56 \\
\hline \multicolumn{4}{|c|}{ National Parks grand totals, $\mathrm{n}=1,054$} \\
\hline Bark beetles & 45 & 53 & 31 \\
\hline Wood borers & 40 & 48 & 28 \\
\hline Stain fungi & 39 & 55 & 13 \\
\hline Insects (beetles and borers) & 53 & 59 & 41 \\
\hline
\end{tabular}

\begin{tabular}{lccc}
\hline & Colorado State Parks grand totals, $\mathrm{n}=56$ & \\
Bark beetles & 67 & 67 & - \\
Wood borers & 57 & 57 & - \\
Stain fungi & 79 & 79 & - \\
Insects (beetles and borers) & 71 & 71 & - \\
\hline
\end{tabular}

Note: Weighted mean percentages are given for state totals: weighting factor was computed from total campers for each park in 2008 divided by the number of campers interviewed in 2009. bination of heat treatment drying and de-barking may be needed to eliminate the risk of forest pest transport.

The genera of firewood was predominantly pine, but campers also transported oak, ash, aspen, and other hardwoods to National Parks in almost every state, even though the percentages were lower than conifers (Table 4 ). Although only $<1 \%$ to $12 \%$ of all wood brought to National Parks were hardwood species, $14 \%$ to $91 \%$ of this wood had bark attached, which substantially increases the risk of pest survival in wood and equates to several thousand campers bringing hardwood with bark into parks based on the millions of visitors to parks each year (all parks surveyed sold only conifer) (Table 4). Historically, several major tree pests that utilize hardwood hosts have been vectored to new areas through untreated wood transport including the pathogen responsible for oak wilt, Asian long-horned beetle, the pathogen responsible for sudden oak death, and most recently and notably, the emerald ash borer (Poland et al. 1998; Crocker et al. 2007; Cushman and Meentenmeyer 2008; Juzwik et al. 2008). The proportion of pine was high in states that had the lowest amounts of out-of-state firewood brought in (Colorado and Wyoming), while campers in states like Nevada had more diverse mixes of different types and genera of firewood and more out-of-state wood was brought in (Tables 3; Table 5). This suggests that parks with known local wood sources available to the public (i.e., mountain pine beetle killed pine trees) may sell more locally-cut firewood to visitors.

If firewood were locally cut or purchased and burned close to the source, then the risks of pest movement are lowered. Overall, most firewood was purchased inside the park; however large proportions were also purchased outside the park from retail stores. Out of all National Park campers who transported wood from home (17\% overall), similar proportions brought wood from the park state, neighboring states, and nonneighboring states (14\% to $21 \%$ ) indicating this type of transport occurs both locally and over longer distances (Table 4). Twenty-five and $26 \%$ of campers visiting parks in Utah and Nevada brought wood 
cut or collected from home into the states, respectively, while other state proportions ranged from only $9 \%$ to $15 \%$ (Table 4).

Campers brought wood from the dead or dying tree in their yard at home in several instances. When the transport is long distance, homeowners are potentially transporting common urban pests to new areas and states, especially if the wood is not properly seasoned. While the study authors did not determine the age of the wood in the surveys, other firewood surveys in the Midwest have shown that campers do move green firewood. Of the firewood pieces confiscated as noted in Michigan surveys, $47 \%$ appeared to have been cut from live trees in the previous year, a surprising result since older wood is drier and generally burns easier, cleaner, and hotter (Haack et al. 2010).

There was no determination if live insects occurred in or on firewood, but most firewood observed showed evidence of previous insect or fungal infestation (Table 6). While most Cerambycid species complete their life cycle in one year, some species (including Prionus and some Goes species) may take two to five years to fully develop and emerge (Craighead 1923). Petrice and Haack $(2006$; 2007) observed various stages of EAB larval development when infested wood was cut and dissected and determined it could take two summers for all the adults to emerge. Since fungi can remain viable for several years in bark and wood (Koski and Jacobi 2004), the presence of previous infestation indicates the firewood may still be infested and act as a source of viable inoculum. There are also several examples of relationships between pathogens, insects, and parasites that could increase the risk of spread of fungi in western states. These include the mountain pine beetle (Dendroctonus ponderosae) and blue stain fungi complex; pine wilt disease, where nematodes are vectored by longhorned beetles; and thousand cankers disease of black walnut, where the fungus (Geosmithia morbida sp. nov) is vectored by a twig beetle (Robinson 1962; Linit 1988; Kolarik et al. 2010). Research is underway at Colorado State University to quantify the number and genera of live insect infestations in untreated, commercially available firewood in the southern Rocky Mountains.

To successfully establish or cause any risk, a receptive host needs to be present nearby when the transported fungus or insect moves from firewood. It is believed that suitable hosts are nearby given the proximity of large National and State Parks to urban or natural forests. For example, several State Park campgrounds surround reservoirs within the suburbs of Denver, Colorado, and the main visitor center at Rocky Mountain National Park is $4 \mathrm{~km}$ from downtown Estes Park, Colorado, a popular city for park visitors and other tourists. Boulder City, a suburb of Las Vegas, Nevada, is $6.4 \mathrm{~km}$ from Lake Mead NRA, which received more than 300,000 campers in 2008 (NPS Statistics 2008). Exotic organisms are likely to become pests when introduced into new areas, and urban forests are usually the first to be invaded (Liebhold 1995). Notable past introductions of highly destructive exotic organisms, including chestnut blight, gypsy moth, and EAB, were all introduced or discovered in urban or suburban areas (Liebhold 1995; Haack et al. 2002). While ash species are not common in the native conifer forests of the western U.S., green ash (Fraxinus pennsylvanica) is present in urban areas throughout the west and has naturalized in many riparian areas in the plains of Colorado and Wyoming. Many Colorado State Park campgrounds are surrounded by eastern or plains cottonwoods (Populus deltoides) and most National Park campgrounds in the west have an aspen component. There are also some regions in the western U.S. without high popula- tions of mountain pine beetle, and campers who move infested wood from home or other campgrounds may transport primary or secondary bark beetles if the wood is not properly seasoned.

\section{Reducing the Risk of Native or Exotic Pests in Firewood}

The potential for campers to transport firewood in the Southern Rocky Mountains was quantified based on surveys from 13 National and seven Colorado State Parks. Although the number of campers transporting firewood in these 20 parks was under 0.5 million per year, the probable risk is increased by millions per year based on other popular travel destinations in the west. The probability of destructive insects or pathogens being present in firewood is apparent since the origin is generally that of dead trees. The federal, state, and county quarantines of firewood movement from infested areas also recognize the risk of moving various pests via firewood (USDA APHIS 2010). Because campers are transporting firewood to parks from nonwestern origins and even from EAB infested states, and State and National Parks, urban communities and tree health professionals should be discouraging the movement of untreated firewood from state to state and not relying entirely on commercial or federal quarantines, especially given the current knowledge of EAB movement via firewood. The National Firewood Task Force recommends that all federal, state, and private parks, forests, and campgrounds encourage the use of local wood and institute policies to discourage campers from moving wood out of the local area (NPB 2010). These entities are encouraged to sell local or treated firewood on site, make available a list of nearby retailers selling local or treated wood, and to institute a firewood exchange program (NPB 2010). Neither agencies nor forest health professionals can always predict the next major forest pest introduction or foretell the pest's native range or preferred hosts, therefore the movement of all species of firewood should be discouraged, not just those associated with known pests.

Impacts to forest resources may be reduced if public education on the potential dangers of long-distance movement of firewood is increased, and if industry professionals learn how to manage and restrict the movement of infested wood (Lawrence 2006, NPB 2010). Firewood consumers were often unaware of the risks involved in moving infested firewood. These surveys offered opportunities to inform and educate campers. In many cases, campers were completely unaware of the risks and were very receptive to the educational opportunity. The National Firewood Task Force recommends that agencies should form a communication steering committee, develop online hubs of firewood outreach materials, and prioritize outreach activities that can be reasonably accomplished for educational purposes (NPB 2010). Directing educational efforts to specific target groups is one way to minimize risks of firewood movement. State Parks throughout the west should target all out-of-state visitors, especially those from nonwestern states, by providing information on of the dangers of transporting firewood when making reservations or prior to arriving at campgrounds. This could be accomplished by mailing literature to those who reserve campsites or on park websites so future visitors see the information while planning trips. Education at National Parks should also be aimed towards out-of-state visitors during the reservation process or prior to arrival. Eighty-three percent of the 47,350 campers with firewood from nonwestern state origins 
were campers from nonwestern states (Table 3), indicating that parks will have to aggressively educate visitors to not travel with firewood and advertise when firewood is available on-site. Some states, including Nevada and Utah, had much higher out-of-state firewood importation compared to other states, and parks in these states should specifically target more educational messages to potential visitors. Many of the $12 \%$ of campers who lived in the park state but had firewood from an out-of-state origin had been traveling throughout the western United States from park to park on common and popular vacation routes. National Parks should also aim educational efforts to residents to not move firewood back to their home state after traveling to parks in other states.

Because State Park, National Park, the Bureau of Land Management, the USDA Forest Service, and other local and federal lands in the west are known as popular locations for hiking, camping, horseback riding, rafting, boating, and fishing, an overly generic and unifying message regarding invasive species should be adopted to avoid sending the public conflicting or confusing information. The NFTF also recommends that agencies should agree on a core message for consistency when educating people on the risks of moving firewood, such as "Don't Move Firewood" (NPB 2010). The study authors recommend that federal, state, and local agencies develop an educational message, such as "Don't Move Exotic Organisms," which combines the concerns for exotic forest pests, plants (such as the certified weed-free feed program), and animals [such as the boater inspection regulations to protect waters from exotic aquatic organisms such as the zebra mussel (Dreissena polymorpha)] (Colorado Dept. of Wildlife 2010).

\section{CONCLUSIONS}

The movement of untreated firewood occurs over short and long distances and has the potential to be a high-risk pathway for the transport of live tree pests. The cost of exotic invasions in urban and natural forests has proven to be economically and ecologically depleting. The following recommendations, if adopted, will help prevent the movement of destructive pests by reducing the risk of pest movement on firewood and related products:

- Include firewood as a risk pathway in all federal, state, and local exotic species education efforts.

- Parks and campgrounds should ban all firewood that is not treated or produced locally.

- Parks and campgrounds should promote local wood sales to incoming visitors prior to their arrival.

- Parks and campgrounds should provide locally cut or heattreat, dry firewood for free or at average market cost.

- States should ban or closely regulate the movement of untreated firewood across state borders.

- Arborists should ensure that the firewood, mulch, wood chips, and other unprocessed wood they produce is free of native or exotic pests.
Acknowledgments. Funding for National Park surveys was provided by USDA-APHIS-PPQ Center for Plant Health Science and Technology (CPHST). State Park surveys were funded by Colorado Cooperative Agricultural Pest Survey (CAPS). We appreciate all the permit assistance from Colorado State Parks and National Park Service staff members, Megan McBride with the Social Science Program of the NPS, and Phyllis Pineda Bovin from Great Sand Dunes National Park and Preserve for collecting and providing visitor data. We appreciate the hard work of Jim Morrow and Nathan McBride in helping conduct surveys. We recognize the advice and expertise of Jim zumBrunnen (Franklin A. Graybill Statistical Laboratory, Colorado State University) in experimental design and statistical analyses. Special thanks to Dr. Judith E. Pasek (USDA-APHIS), Les Koch (Wyoming State Forestry Division), Janet G. Hardin (CSU) and Lisa Perino (USDA-APHIS) for thorough and helpful reviews of an earlier version of this manuscript. The authors also thank Dr. Alan J. Sawyer and Vic Mastro (both USDA-APHIS-PPQ CPHST), the journal editor and two anonymous individuals for their review and helpful suggestions of the submitted manuscript

\section{LITERATURE CITED}

Allen, E.A., and L.M. Humble. 2002. Nonindigenous species introductions: a threat to Canada's forests and forest economy. Canadian Journal of Plant Pathology 24:103-110.

Beck, K.G., K. Zimmerman, J.D. Schardt, J. Stone, R.R. Lukens, S. Reichard, J. Randall, A.A. Cangelosi, D. Cooper, and J.P. Thompson. 2008. Invasive species defined in a policy context: recommendations from the Federal Invasive Species Advisory Committee. Invasive Plant Science and Management 1:414-421.

BenDor, T.K., S.S. Metcalf, L.E. Fontenot, B. Sangunett, and B. Hannon. 2006. Modeling the spread of the emerald ash borer. Ecological Modeling 197:221-236.

Craighead, F.C. 1923. North American cerambycid larvae; a classification and biology of the North American cerambycid larvae. Canadian Department of Agriculture Technical Bulletin No. 27.

Crocker, S.J., G.J. Brand, and D.C. Little. 2007. Illinois' Forest Resources, 2005. Resource Bulletin NRS-13. Newton Square, PA: U.S. Department of Agriculture, Forest Service, Northern Research Station. 36 pp.

Colorado Department of Wildlife. 2010. Wildlife Species, Invasive Species, Zebra and Quagga Mussels. <http://wildlife.state.co.us/WildlifeSpecies/Profiles/InvasiveSpecies/ZebraandQuaggaMussels.htm>

Cushman, J.H., and R.K. Meentemeyer. 2008. Multi-scale patterns of human activity and the incidence of an exotic forest pathogen. Journal of Ecology 96:766-776.

Desprez-Loustau, M.-L., C. Robin, M. Buée, R. Courtecuisse, J. Garbaye, F. Suffert, I. Sache, and D.M. Rizzo. 2007. The fungal dimension of biological invasions. Trends in Ecology and Evolution 22:472-480.

Dunbar, D.M., and G.R. Stephens. 1974. Twolined chestnut borer: Effects of storage conditions, processing, and insecticides on its survival in oak logs. Journal of Economic Entomology 67:427-429.

Haack, R.A., E. Jendek, H. Liu, K.R. Marchant, T.R. Petrice, T.M. Poland, and H. Ye. 2002. The emerald ash borer: A new exotic pest in North America. Newsletter of the Michigan Entomological Society, September 2002. 47(3\&4):1-4.

Haack, R.A. 2006. Exotic bark- and wood-boring Coleoptera in the United States: recent establishments and interceptions. Canadian Journal of Forest Resources 36:269-288. 
Haack, R.A., and T.R. Petrice. 2007. How risky is bark that is associated with treated wood packing material? 2007 USDA Interagency Research Forum - GTR-NRS-P-28. < http://nrs.fs.fed.us/pubs/gtr/ gtr_nrs-p-28papers/18haack-p-28.pdf>

Haack, R.A., and T.R. Petrice. 2009. Bark- and Wood-Borer Colonization of Logs and Lumber After Heat Treatment to ISPM 15 Specifications: The Role of Residual Bark. Journal of Economic Entomology 102:1075-1084.

Haack, R.A., T.R. Petrice, and A.C. Wiedenhoeft. 2010. Incidence of Bark- and Wood-Boring Insects in Firewood: A Survey at Michigan's Mackinac Bridge. Journal of Economic Entomology 103:1682-1692.

Juzwik, J., T.C. Harrington, W.L. MacDonald, and D.N. Appel. 2008. The origin of Ceratocystis fagacearum, the oak wilt fungus. Annual Review of Phytopathology 46:13-26.

Koralik, M., Freeleand, E., Utley, C. and N. Tisserat. 2010. Geosmithia morbida sp. nov., a new phytopathogenic species living in symbiosis with the walnut twig beetle (Pityophthorus juglandis) on Juglans in USA. Mycologia doi:10.3852/10-124.

Koski, R., and W.R. Jacobi. 2004. Tree pathogen survival in chipped wood mulch. Journal of Arboriculture 30:165-171.

Kovacs, K.F., R.G. Haight, D.G. McCullough, R.J. Mercader, N.W. Siegert, and A.M. Liebhold. 2010. Cost of potential emerald ash borer damage in U.S. communities, 2009-2019. Ecological Economics 69:569-578

Lawrence, R.K. 2006. Beyond the Asian longhorned beetle and emerald ash borer. In: L.E. Riley, R.K. Dumroese, T.D. Landis. 2006 National Proceedings: Forest and Conservation Nursery Associations - 2005. Proc. RMRS-P-43. Fort Collins, CO: U.S. Department of Agriculture, Forest Service, Rocky Mountain Research Station. p. 137-140.

Lewis, R.J. 1987. Ceratocystis fagacearum in living and dead Texas live oaks. Res. Note SO-335. New Orleans, LA: U.S. Department of Agriculture, Forest Service, Southern Forest Experiment Station. 4 pp.

Liebhold, A.M., W.L. MacDonald, D. Bergdahl, and V.C. Mastro. 1995. Invasion by exotic forest pests: a threat to forest ecosystems. Forest Science Monographs 30. Bethesda Maryland, USA. 41(2) 49 pp.

Linit, M.J. 1988. Nematode-vector relationships in the pine wilt disease system. Journal of Nematology 20:227-235.

Lovett, G.M., C.D. Canham, M.A. Arthur, K.C. Weathers, and R.D. Fitzhugh. 2006. Forest ecosystem response to exotic pests and pathogens in eastern North America. BioScience 56:395-405.

Mayfield, A.E. 2007. Laurel wilt, a serious threat to Redbay and other related native plants. The Palmetto 24:8-11.

McCullough, D.G., T.M. Poland, D. Cappaert, E.L. Clark, I. Fraser, V. Mastro, S. Smith, and C. Pell. 2007. Effects of chipping, grinding, and heat on survival of emerald ash borer, Agrilus planipennis (Coleoptera: Buprestidae), in chips. Journal of Economic Entomology 100:1304-1315

Michigan Department of Agriculture (MDA). 2006. Michigan.gov. $<$ http://www.michigan.gov/documents/mda/mda_EAB_Firewood_ Fact_Sheet_181108_7.pdf.>

Muirhead, J.R., B. Leung, C. vanOverdijk, D.W. Kelly, K. Nandakumar, K.R. Marchant, and H.J. MacIsaac. 2006. Modeling local and long distance dispersal of invasive emerald ash borer Agrilus planipennis (Coleoptera) in North America. Diversity and Distributions 12:7-79.

National Plant Board (NPB). 2010. National Prewood task force recommendations. March 2010. 21 pp. <http://nationalplantboard.org/docs/ NFTF_Recommendations_Final_March_2010_1.doc>.
National Park Service. 2008. National Park Service Public Use Statistics Office. Retrieved December 16, 2009. <http://www.nature.nps.gov/ stats/index.cfm>

Petrice, T.R., and R.A. Haack. 2006. Effects of cutting date, outdoor storage conditions, and splitting on survival of Agrilus planipennis (Coleoptera: Buprestidae) in firewood logs. Journal of Economic Entomology 99:790-796.

Petrice, T.R., and R.A. Haack. 2007. Can emerald ash borer, Agrilus planipennis (Coleoptera: Buprestidae), emerge from logs two summers after infested trees are cut? The Great Lakes Entomologist 40:92-95.

Pimentel, D., R. Zuniga, and D. Morrison. 2005. Update on the environmental and economic costs associated with alien-invasive species in the United States. Ecological Economics 52:273-288.

Poland, T.M, R.A. Haack, and T.R. Petrice. 1998. Chicago joins New York in battle with the Asian longhorned beetle. Newsletter of the Michigan Entomological Society 43:15-17.

Poland, T.M., and D.G. McCullough. 2006. Emerald ash borer: invasion of the urban forest and the threat to North America's ash resource. Journal of Forestry 104:118-124.

Rizzo, D.M., and M. Garbelotto. 2003. Sudden oak death: endangering California and Oregon forest ecosystems. Frontiers in Ecology and the Environment 1:197-204.

Robinson, R. 1962. Blue stain fungi in lodgepole pine (Pinus contorta Dougl. var. latifolia Engelm.) infested by the mountain pine beetle (Dendroctonus monticolae Hopk.) Canadian Journal of Botany 40:609-614.

Rossman, A.Y. 2001. A special issue on global movement of invasive plants and fungi. Bioscience 51:93-94.

Sydnor, T.D., M. Bumgardner, and A. Todd. 2007. The potential economic impacts of emerald ash borer (Agrilus planipennis) on Ohio, U.S., communities. Arboriculture \& Urban Forestry 33:48-54.

Tkacz, B.M. 2002. Pest risks associated with importing wood to the United States. Canadian Journal of Plant Pathology 24:111-116.

United States Department of Agriculture (USDA) Animal and Plant Health Inspection Service (APHIS). Cooperative Emerald Ash Borer Project. Updated July 8, 2010. Distribution Map <http://www.aphis. usda.gov/plant_health/plant_pest_info/emerald_ash_b/downloads/ multistateeab.pdf>

William R. Jacobi (corresponding author)

Department of Bioagricultural Sciences and Pest Management

Colorado State University

1177 Campus Delivery

Fort Collins, CO 80523-1177, U.S.

William.jacobi@colostate.edu

Betsy A. Goodrich

Department of Bioagricultural Sciences and Pest Management Colorado State University

1177 Campus Delivery

Fort Collins, CO 80523-1177, U.S

Christy Cleaver

Department of Bioagricultural Sciences and Pest Management Colorado State University

1177 Campus Delivery

Fort Collins, CO 80523-1177, U.S 
Résumé. Le bois de chauffage non traité peut potentiellement abriter des insectes ou des agents pathogènes nocifs pour les arbres en milieu urbain et pour les écosystèmes naturels. Les campeurs de 15 site de camping regroupés au sein de sept parcs de l'état du Colorado ainsi que ceux de 30 sites regroupés au sein de 13 parcs nationaux en Arizona, au Colorado, au Nevada, en Utah et au Wyoming ont été sondés entre 2007 et 2009 afin de déterminer leur état d'origine, la présence ou non de bois de chauffage sur le site de camping, l'état d'origine du bois de chauffage et les risques que ce bois serve d'abris pour des parasites nuisibles. Soixante six pourcent des campeurs dans les parcs de l'état du Colorado avaient du bois de chauffage, mais seulement $4 \%$ d'entre eux avaient amenés du bois provenant d'un autre état. Soixante pourcent des campeurs dans les parcs nationaux avaient du bois de chauffage et $39 \%$ d'entre eux avaient amené leur bois de chauffage depuis un autre état, ce qui équivalait à 239919 campeurs qui avaient amenés leur bois de chauffage depuis un autre état dans une même année. Quarante et un pourcent du bois de chauffage amené depuis un autre état provenait d'un état qui était non limitrophe à celui où se trouvait le site de camping, ce qui était indicateur d'un transport de bois de chauffage sur une longue distance. De tous le bois de chauffage présent dans les parcs nationaux, $32 \%$ était acheté à l'intérieur même du parc, 25\% l'était à l'extérieur du parc et $17 \%$ provenait de la résidence même du campeur. Cinquante-trois pourcent du bois de chauffage présentait des indices d'une présence antérieure d'insecte et $39 \%$ présentait des indices d'une infestation fongique. Le transport par les campeurs de bois de chauffage non traité comporte un potentiel de risque élevé de dissémination de parasites vivants au travers tout l'Amérique du Nord; des actions d'éducation et de mitigation doivent donc être mises en place.

Zusammenfassung. Unbehandeltes Feuerholz hat das Potential Insekten oder Pathogene zu beherbergen, die tötlich auf Bäume in urbanen und natürlichen Ökosystemen wirken können. Camper auf 15 Campingplätzen in sieben Parks in Colorado, USA, und 30 Campingplätze in 13 Nationalparks in Arizona, Colorado, Nevada, Utah, und Wyoming wurden im September 2007 befragt, um die Heimatbundesstaaten der Camper zu erfassen, die Feuerholzpräsenz, die Herkunft des Feuerhol- zes und die Risiken von eingeschleppten Krankheiten durch Feuerholz. $66 \%$ der Colorado-State-Park-Camper hatten Feuerholz, aber nur $4 \%$ hatten das Feuerholz von außerhalb des Bundesstaates, was bedeutet, dass 329.919 Camper innerhalb des befragten Zeitraums von einem Jahr ihr Feuerholz von außerhalb mitgebracht hatten. $41 \%$ des eingeführten Feuerholzes stammt aus nicht benachbarten Bundesstaaten, was darauf hinweist, dass ein langer Feuerholztransport vorkommt. Von der Gesamtmenge des Feuerholzes in den Nationalparks wurden $32 \%$ innerhalb des Park gekauft, $25 \%$ wurde außerhalb des Parks erworben und $17 \%$ stammen aus dem Privatbesitz der Camper. 53\% des Feuerholzes besass Anzeigen von Insektenpräzenz und $39 \%$ war von Pilzen befallen. Die Bewegung von unbehandeltem Feuerholz durch Camper birgt das Potential eines hohen Risikos der Verschleppung von lebenden Schaderregern in den ganzen USA und erzieherische und eingreifende Aktionen sollten implementiert werden.

Resumen. La leña para combustible no tratada tiene el potencial de proteger insectos o patógenos letales para los árboles en los ecosistemas naturales. Fueron encuestados en 2007-09 los campers en 15 campamentos en siete campos de parques estatales de Colorado, U.S., 30 campamentos en 13 parques en Arizona, Colorado, Nevada, Utah y Wyoming, para determinar el estado de las casas, presencia de fogatas, origen de la leña y riesgos de plagas. Sesenta y seis por ciento de los campers del Parque Estatal de Colorado tuvo leña pero solamente 4\% era comprada afuera del estado de origen, igualando a 329,919 campers que lo traen de afuera en un año. Cuarenta y uno por ciento de la leña fue comprada por campers de estados vecinos, indicando que ocurre transporte de leña de largas distancias. De toda la leña presente en los Parques Nacionales, $32 \%$ fue comprada dentro del parque, $25 \%$ fue comprada afuera del parque y $17 \%$ de camper residentes. Cincuenta y tres por ciento de la leña tiene evidencia de presencia previa de insectos y $39 \%$ tiene infestación de hongos. El movimiento en los campers de leña no tratada tiene alto potencial de riesgo de servir para la distribución de plagas de árboles vivos a través de Norte América, y las acciones de educación y mitigación deberían ser implementadas. 